\title{
Changes in 18F-FDG PET-CT Appearances of Treated Malignant Melanoma Metastases within the Right Atrium
}

\author{
Tedavi Edilmiş Sağ Atriyum Malign Melanom Metastazlarının ${ }^{8}$ F-FDG PET-BT \\ Görüntülerindeki Değişiklikleri
}

Luke lenari Sonoda, Bal Sanghera, Katharine Nowlan, Emma Roantree, Thomas Wagner, Paul Nathan

Mount Vernon Hospital, Paul Strickland Scanner Centre, London, United Kingdom

\begin{abstract}
18F-FDG PET-CT plays an important role in the management of malignant melanoma. Cardiac metastases of melanoma are relatively uncommon, but when present they often manifest with cardiac arrhythmia and cardiac failure. Once treated successfully, lesions in the heart reduce in size and FDG-uptake, while signs of cardiac arrhythmia and cardiac failure may resolve. With a background of normal physiological FDG-uptake in cardiac muscle, a careful observation is required when cardiac metastases are clinically suspected. We report a patient with right atrial metastases of melanoma who presented with new onset atrial fibrillation, and in whom the cardiac lesion reduced in size and FDG-uptake following appropriate treatment, and signs of cardiac arrhythmia spontaneously resolved. The authors believe this is the first set of PET-CT appearances of pretreatment and treated cardiac metastases of melanoma in the literature.
\end{abstract}

Key words: PET and CT, melanoma, neoplasm metastasis, heart atria, atrial fibrillation

Conflicts of Interest: The authors reported no conflict of interest related to this article.

\begin{abstract}
Özet
18F-FDG PET-BT malign melanom tedavisinde önemli bir rol oynamaktadır. Kardiak melanom metastazı oldukça nadir görülmekle birlikte bulunması durumunda kardiyak aritmi ve kalp yetmezliğine yol açabilir. Başarılı bir tedavi ile kalpteki lezyonlar küçülerek FDG-tutulumu azalabilir, kardiyak aritmi ve kalp yetmezliği bulguları da gerileyebilir. Kalp kasında normal fizyolojik FDG-tutulumu olduğundan kalp metastazından şüphelenilen klinik durumlarda dikkatli bir değerlendirme gereklidir. Bu olgu sunumunda yeni başlangıçlı atriyal fibrilasyon ile belirti veren, sağ atriyal malign melanom metastazı olan, uygun tedaviyi takiben kardiak lezyon boyutu ile FDG-tutulumunda azalma saptanan ve kardiyak aritminin spontan gerilediği bir hasta bildirilmektedir. Yazarlar kardiyak melanom metastazına ait tedavi öncesi ve sonrası PET-BT görüntülerinin literatürde ilk kez belirtildiğini düşünmektedir.
\end{abstract}

Anahtar kelimeler: PET ve BT, melanom, neoplazm metastaz, kalp atriyumu, atriyal fibrilasyon

Çıkar Çatışması: Yazarlar bu makale ile ilgili olarak herhangi bir çıkar çatışması bildirmemiştir.

\section{Introduction}

18F-FDG PET-CT has an active role in staging of metastatic melanoma. Although intra-cardiac metastases of melanoma are relatively uncommon, a careful observation of cardiac FDG-uptake is required if there are new signs and symptoms of cardiac arrhythmia. Cardiac muscle has intrinsic high FDG-uptake, hence it is often difficult to visualize abnormal foci of FDG-uptake. Contrast-

Address for Correspondence: Luke lenari Sonoda MD, Mount Vernon Hospital, Paul Strickland Scanner Centre, London, United Kingdom Phone: +44-02075867410 E-mail: luke@sonoda.co.uk Received: 01.07.2013 Accepted: 28.08.2013 
enhanced $\mathrm{CT}$ of the heart may further assist in visualizing the location of abnormal intra-cardiac lesions.

\section{Case Report}

A 52-year-old man was referred for an FDG-PET-CT-scan with clinical suspicion of parotid malignancy, and with recent onset atrial fibrillation. The scan demonstrated extensive metastatic disease including cervical and retroperitoneal lymphadenopathy, lung, renal, adrenal, bone and subcutaneous metastases (Figure 1a). In particular, there was a $57 \mathrm{~mm}$ focus of intense FDG uptake (SUVmax 23.9) seen within the right atrium suggestive of intra-cardiac metastatic disease (Figure $1 \mathrm{~b}$ arrows, at two axial levels within the heart). This may explain the new onset of atrial fibrillation. Cervical nodal biopsy confirmed metastatic melanoma. Echocardiogram confirmed a lesion in the right atrium (not shown). The patient was then given a course of oral Vemurafenib 960 mg once a day, a standard treatment for metastatic melanoma. The patient had mixed response to therapy. Overall there was decrease in the FDG avid disease burden and in the intensity of the uptake in previously detected lesions. However, there were a few new skeletal lesions compared to the pre-treatment scan (Figure 1e). After the treatment, the right atrial mass reduced in maximum size by $28 \%(41 \mathrm{~mm})$, and FDG-uptake reduced by $60 \%$ (SUVmax 9.6) (Figure 1c arrow, at the same two axial levels as Figure $1 \mathrm{~b}$ ). Contrast-enhanced CT demonstrated residual atrial disease (Figure 1d arrow). The symptom of atrial fibrillation spontaneously resolved.

\section{Literature Review and Discussion}

Most malignant melanoma subtypes are known to be FDGavid $(1,2)$, hence 18 F-FDG PET-CT has been commonly used in the management of malignant melanoma, in particular, for staging and monitoring response to therapy (3).

Cardiac metastases of melanoma are relatively uncommon $(4,5)$, but when it occurs it often manifests with cardiac signs such as cardiac arrhythmia and cardiac failure $(4,6)$. Other signs and symptoms of cardiac metastases include ventricular inflow obstruction, embolism, valvular heart disease, syncope and pericardial effusion (7). Atrial fibrillation usually accompanies right atrium metastases $(8,9)$.

Primary FDG-avid cardiac tumors are rare, and histologically over three-quarters of primary heart tumors turn out to be benign, almost half of them being myxomas (7).

Other common malignancies that present with cardiac metastases are carcinoma of the lung, breast, oesophagus, lymphoma and leukaemia (7).

Although stage 4 metastatic melanoma is rarely curable, a few new approaches have shown clinical benefit by prolonging overall survival in randomized trials (10). Current treatment regimes of stage 4 melanoma include chemotherapy and immunotherapy (11). One of the most promising treatment options is oral Vemurafenib, a standard treatment for metastatic melanoma (12). Vemurafenib plays a role by inhibiting the mitogenactivated protein (MAP) kinase pathway in patients whose tumors have a V600 mutation in the BRAF gene $(13,14,15,16)$.

Our patient was given oral Vemurafenib 960 mg once a day, and the cardiac lesion demonstrated partial response to therapy. The cardiac lesion has reduced in size and FDGavidity, and the symptom of atrial fibrillation has resolved appropriately (17).
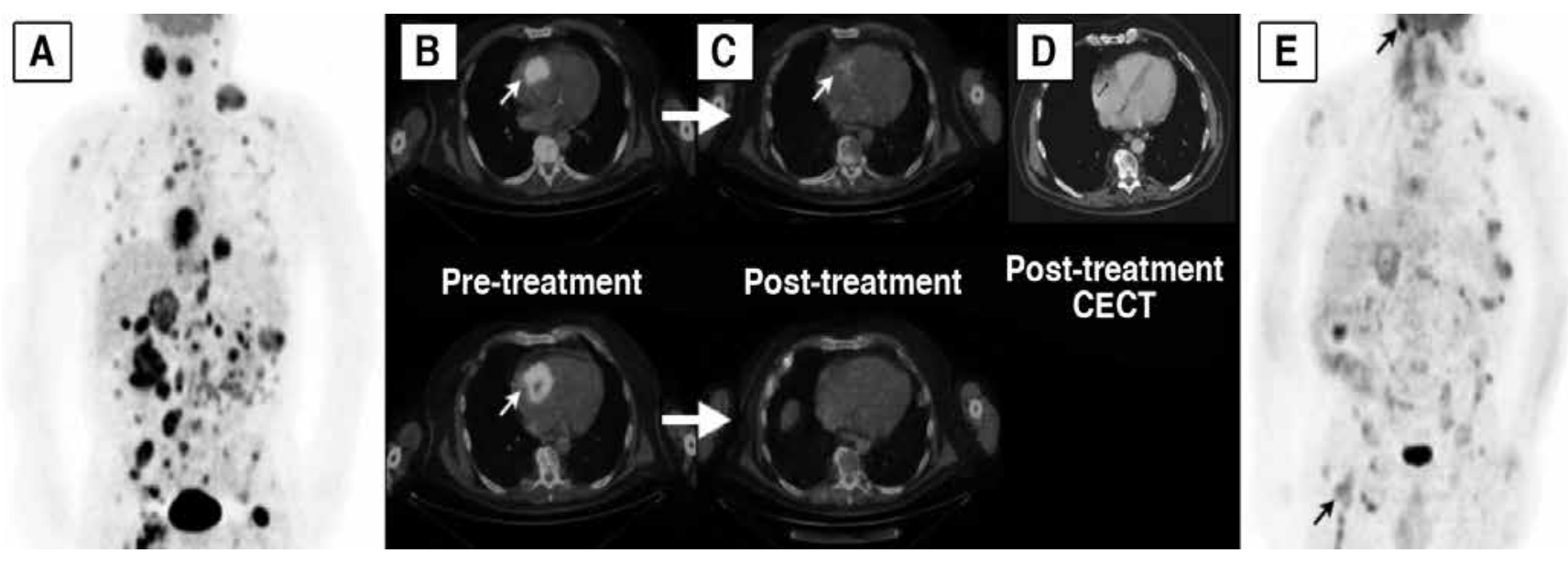

Figure 1. a: MIP image of whole body 18F-FDG PET pre-treatment scan demonstrates multiple foci of abnormal FDG-uptake due to metastatic melanoma. b: Fused pre-treatment PET-CT images, two different axial slices through the right atrium demonstrate a large focus of intensely FDG-avid right atrial metastases. c: Fused post-treatment PET-CT images, two axial slices same as Figure 1b. The right atrial lesion has significantly reduced in size and in FDG-avidity. $\mathrm{d}$ : Contrast-enhanced CT (CECT) at the same axial level (post-treatment scan) delineates the residual right atrial lesion more clearly. e: MIP image of whole body 18F-FDG PET post-treatment scan demonstrates mixed response to therapy, with reduced FDG uptake of multiple foci of metastatic melanoma, but with a few new skeletal lesions, such as right skull base and right proximal femur (arrows) 
As the cardiac muscle demonstrates normal physiological FDG-uptake, it is often hard to visualize/ localize a possible intra-cardiac metastatic focus. Contrastenhanced CT or echocardiography may assist identifying such lesions by delineating the cardiac mural surface, as shown in our case (18).

\section{References}

1. Sebro R, Mari-Aparici C, Hernandez-Pampaloni M. Value of true whole-body FDG-PET/CT scanning protocol in oncology: optimization of its use based on primary diagnosis. Acta Radiol. 2013;54:534539.

2. Ortega Candil A, Rodríguez Rey C, Carreras Delgado JL. Malignant melanoma. ISRN Dermatol 2012;2012:308279.

3. Schröer-Günther MA, Wolff RF, Westwood ME, Scheibler FJ, Schürmann C, Baumert BG, Sauerland S, Kleijnen J. F-18-fluoro2-deoxyglucose positron emission tomography (PET) and PET/ computed tomography imaging in primary staging of patients with malignant melanoma: a systematic review. Syst Rev 2012;1:62

4. Cheruvu B, Cheruvu P, Boyars M. An unusual case of metastasis to the left side of the heart: a case report. J Med Case Rep 2011;5:23.

5. Tas F, Mudun A, Kirma C. Cardiac involvement in melanoma: a case report and review of the literature. J Cancer Res Ther 2010;6:359-361.

6. Leja MJ, Kim M, Perryman L, Blackmon SH, Reardon MJ. Metastatic melanoma to the intracavitary left ventricle treated using cardiac autotransplantation technique for resection. Methodist Debakey Cardiovasc J 2011;7:44-46

7. Reynen K, Köckeritz U, Strasser RH. Metastases to the heart. Ann Oncol 2004;15:375-381.
8. Pinho T, Rodrigues-Pereira P, Araújo V, Oliveira NP, Macedo F, Graça A Maciel MJ. Cardiac metastasis of melanoma as first manifestation of disease. Rev Port Cardiol 2009;28:633-639.

9. Allen BC, Mohammed TL, Tan CD, Miller DV, Williamson EE, Kirsch JS. Metastatic melanoma to the heart. Curr Probl Diagn Radiol 2012:41:159-164

10. Fox $M C$, Lao CD, Schwartz JL, Frohm ML, Bichakjian CK, Johnson TM. Management options for metastatic melanoma in the era of novel therapies: A primer for the practicing dermatologist: Part II: Management of stage IV disease. J Am Acad Dermatol 2013:68:1-13.

11. Khan KH, Goody RB, Hameed H, Jalil A, Coyle VM, McAleer Jj. Metastatic melanoma: a regional review and future directions. Tumori 2012;98:575-580.

12. Dean $E$, Lorigan P. Advances in the management of melanoma: targeted therapy, immunotherapy and future directions. Expert Rev Anticancer Ther 2012:12:1437-1448.

13. Menzies AM, Long GV, Murali R. Dabrafenib and its potential for the treatment of metastatic melanoma. Drug Des Devel Ther 2012;6:391-405.

14. Liszkay G. (Vemurafenib (Zelboraf) in the therapy of melanoma) Magy Onkol 2013;57:110-113.

15. Mackiewicz J. What is new in the treatment of advanced melanoma? State of the art. Contemp Oncol (Pozn) 2012;16:363-370.

16. Tsai KY, Nowroozi S, Kim KB. Drug safety evaluation of vemurafenib in the treatment of melanoma. Expert Opin Drug Saf 2013 DOI: 10.1517/14740338.2013.813017

17. Tocchetti CG, Lombari MC, Librera M, Ascierto PA, Maurea N. Complete atrioventricular block in a patient with intracardiac metastases from malignant melanoma. Eur J Echocardiogr 2011;12:636.

18. Onan B, Onan IS, Polat B. Surgical resection of solitary metastasis of malignant melanoma to the right atrium. Tex Heart Inst J 2010;37:598-601. 